coronary artery bypass graft surgery patients $>75$ years old. Gen Thorac Cardiovasc Surg. 2012;60(4):217-224.

9. Gimbel ME, Willemsen LM, Daggelders MC, et al. Long-term follow-up after bypass surgery or coronary stenting in elderly with multivessel disease. Neth Heart J. 2020;28(9):467-477.

10.Gjeilo KH, Wahba A, Klepstad P, Lydersen S, Stenseth R. Survival and quality of life in an elderly cardiac surgery population: 5-year followup. Eur J Cardiothorac Surg. 2013;44(3):e182-188.

\title{
CHẨN ĐOÁN VÀ XỬ TRÍ HAI TRƯờnG HỢP ÁP XE NÃO DO TAI TẠI BỆNH VIỆN CHỢ RẪY
}

\section{TÓM TẮT}

Qua hai trường hợp áp xe não do tai, bệnh nhân đều có hội chứng tăng áp lức nôi so (đau đầu, nôn ói và rối loạn tri giác), hội chứng nhiểm trùng (sốt lạnh run,...) và các triêu chứng của tai (chảy dich tai). Hai trường hợp trên đều xác định chẩn đoán dựa vào triẹu chứng lâm sàng và $C T$ scan/ MRI. Một trường hợp điểu trị phối hợp nội khoa và ngoai khoa (mở sọ bóc ổ áp xe + khoét rống đá chũm). Trường hợp còn lại điều trị nội khoa kết hợp khoét rộng đá chũm. Kết quả thành công tốt cả hai ca. Hai trường hợp phục hồi tốt và xuất viên.

Tư khóa: áp xe não do tai, viêm tai xương chũm biến chứng áp xe não.

\section{SUMMARY \\ DIAGNOSIS \& TREATMENT OF TWO CASE WITH OTOGENIC BRAIN ABCESS AT CHO RAY HOSPITAL}

The patients have high intracranial pressure syndrome (headache, vomit and metal disoder), infectious syndrome (fever with chill, increasing white blood cell,...) and ear problems (ear pain, discharge, pus in mdiddle ear). Two cases were diagnosed to base on clinical symptoms and images (CT scan/ MRI). After diagnosing, the first case have been combined medical treatment and craniotomy to remove total brain abcess. We performed radical mastoidectomy after craniotomy about 1 week. The second case only cure by medical treatment and radical mastoidectomy. Therc arc nice result with two cases. They can go to their home.

Keywords: otogenic brain abcess, mastoid otoginitis with brain abcess.

\section{GIỚl THIÊU}

Áp xe não là một tình trạng nhiễm trùng và viêm của nhu mô não. Tình trạng áp xe não thì không phổ biến, nhưng khi bị áp xe não thì tình trạng bệnh sẽ nghiêm trọng và có thể đe dọa đến tính mạng; và cần được can thiệp sớm để giảm

*Bênh viện Chợ Rẫy

Chịu trách nhiệm chính: Ngô Văn Công

Email: congtmh@gmail.com

Ngày nhân bài: 24.6.2021

Ngày phản biên khoa hoc: 24.8.2021

Ngày duyệt bài: 30.8.2021
Ngô Văn Công*

tỷ lệ biến chứng và tử vong [7]. Các nghiên cứu cho thấy áp xe não không phân biệt độ tuổi, nhưng hơn $1 / 4$ áp xe não được chẩn đoán ở trẻ em và người già [1]. Những năm gần đây, qua các nghiên cứu cho thấy tỷ lệ áp xe não có khuynh hướng giảm do tăng sử dụng kháng sinh [5]. Hiện nay, áp xe não được chẩn đoán sớm và điều tri kịp thời do sư phát triển của CT/ MRI. Do đó, việc hiểu biết về biểu hiện lâm sàng, chẩn đoán sớm và điều trị kịp thời áp xe não giúp cứu sống bệnh nhân. Chính vì vậy, qua ca lâm sàng này, giúp cho các Bác sĩ lâm sàng Tai Mũi Họng tổng quan lại bệnh lý áp xe não do tai.

\section{BÁO CÁO CA LÂM SÀNG}

Trường hợp 1: Ngày 1 tháng 8 năm 2018 với bệnh nhân nam, 19 tuổi vào viện vì đau đầu, nôn ói. Với bệnh sứ là sốt lạnh run, kèm đau đâu nhiều, nôn ói và thay đổi tri giác khoảng 2 tuần. Bên cạnh đó, bệnh nhân còn chảy mủ tai trái, dich hôi và đau tai trái khoảng 3 tuần. Tiền sứ: bệnh nhân thường có những đợt chảy mủ tai trái từ nhỏ và kèm theo nghe kém. Được điêu trị viêm tai giữa ở phòng mạch địa phương. Khám lâm sàng tai thời điểm nhập viên: bênh nhân vẫn còn sốt và ớn lạnh, mạch 105 lần/ phút, huyết áp $110 / 70 \mathrm{mmHg}$ và Glasgow 11 điểm $\left(E_{3} \mathrm{~V}_{4} \mathrm{M}_{4}\right)$. Khám tai trái: chảy nhiêu dịch hôi, thủng $1 / 4$ sau trên thượng nhĩ, nhiều mủ thoát ra khi hút. Các cơ quan khác chưa ghi nhận bất thường. Kết quả CT scan: có khối giảm đậm độ rõ ở vùng thái dương trái, kích thước $4 * 3,5 \mathrm{~cm}$, tròn, có vỏ bao cản quang, và có thông với xương chũm. Có hình ảnh giảm đậm độ trên xương chũm và tiêu mất chuỗi xương con, có hình ảnh mòn xương chũm. Được chẩn đoán áp xe não do tai/ viêm tai xương chũm trái cholesteatoma. Bệnh nhân được điều trị nội khoa với kháng sinh, chống phù não, được phẫu thuật mở sọ thái dương bóc trọn áp xe + kết hợp khoét rộng đá chũm trái và chỉnh hình ống tai sau 1 tuần. Sau phẫu thuật tình trạng bệnh nhân ổn định, hồi phục và xuất viện. 


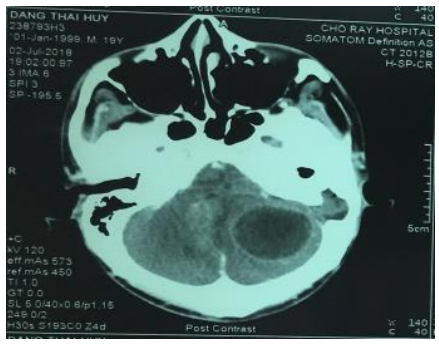

Hình 1: áp xe não

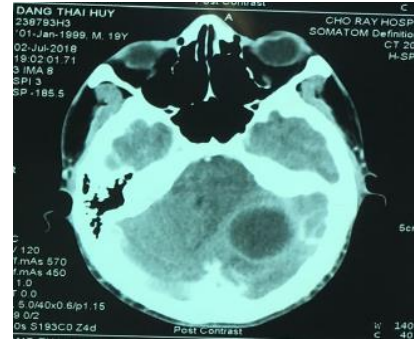

Hình 2: áp xe não có vỏ bao rô

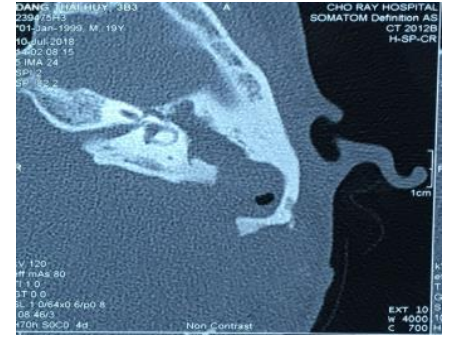

Hinh 3: tôn thương xương chũm (T)
Trường hợp 2: Ngày 15 tháng 8 năm 2020 với bệnh nhân nữ 33 tuối vào viện vì đau đầu và nôn ói nhiều. Bệnh sử: cách nhập viện 1 tuần, bệnh nhân bi sốt lạnh run, kèm chảy mủ tai trái nhiều, hôi. Được uống thuốc điều trị tại bệnh viện địa phương với chẩn đoán viêm tai giữa trái, nhưng tình trạng bệnh không giảm, và nặng hơn. Cách nhập viện 2 ngày bệnh nhân đau đầu nhiều và nôn ói, nên được chuyển viện. Với kết quả $C T$ : có hình ảnh áp xe não vùng thái dương trái, với 2

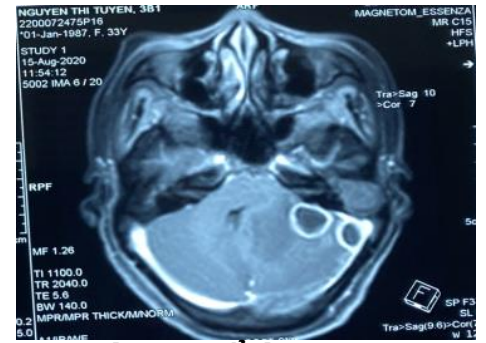

Hình 1: ố áp xe não trên MRI

\section{BÀN LUẬN}

3.1. Dâu hiệu lâm sàng: Triệu chứng lâm sàng trong quá trình áp xe não tùy thuộc vào phân loại, vị trí tổn thương, sự lan rộng của nhiễm trùng, loại vi khuẩn gây bệnh, tình trạng miễn dịch của bệnh nhân. Qua 2 trường hợp, triệu chứng đau đầu và sốt lạnh run là triệu chứng nổi trội nhất. Trong đó, triệu chứng đau đầu là triệu chứng phổ biến nhất của áp xe não và làm bệnh nhân phải nhập viện. Bên canh đó, bệnh nhân có thể biểu hiện các triệu chứng khác như sốt, buồn nôn, ói, thay đổi tri giác và hôn mê. Các bệnh nhân cũng có thể biểu hiện dấu hiệu thần kinh trung ương như liệt $1 / 2$ người, nói khó, mất ngôn ngữ, phù gai thị và mất thị trường. Sự lan rộng nhiếm trùng đến màng não có thể dấn đến các triệu chứng như cứng cổ hoặc tai biến mạch máu não. Bao gồm tổn thương tiểu não cũng phổ biến trong áp xe não do tai; triệu chứng lâm sàng bao gồm thất điều, rối loạn vận động và động mắt [7],[10]. Ngoài ra, áp xe nã̃o nguyên nhân từ tai thường kèm các triệu chứng tai xảy ra trước hoặc đồng thời. Thường bệnh lý ổ áp xe, kích thước $2 * 2 \mathrm{~cm} ; 1 * 1 \mathrm{~cm}$ kế vùng thượng nhĩ; hình ảnh tổn thương toàn bộ vùng xương chũm trái, hủy toàn bộ xương con đến ốc tai. Chẩn đoán áp xe não vùng thái dương do tai/ Viêm tai xương chũm trái do cholesteatoma. Bệnh nhân được điều trị nội khoa 3 tuần, sau đó phẫu thuật khoét rỗng đá chũm trái, được tiếp tục điều trị nội khoa 2 tuần nữa. Sau đó tình trạng bệnh ổn và xuất viện. 
nhân áp xe não bao gồm nhiễm trùng hô hấp trên lập đi lập lại, viêm xoang, viêm tai giữa mạn, chấn thương, người nhận ghép tạng, nhiễm trùng răng, AIDS và hâu phẫu ngoại thần kinh. Phụ thuộc vào vị trí nhiếm trùng ban đầu, loại hệ thần kinh trung ương bị tổn thương. Viêm xoang sàng, xoang bướm dẫn đến nhiếm trùng thùy trán hoặc thùy thái dương của não, đáng kể. Nhiễm trùng tai giữa và xương chũm có thể lan đến hệ thần kinh trung ương bao gồm hầu hết đại não và thùy thái dương. Sự lan truyền đường máu từ vị trí nguyên phát đến hệ thần kinh trung ương như nhiếm trùng răng, áp xe phổi, và nhiễm trùng các cơ quan khác [10]. Bệnh hoc của áp xe não phụ thuộc vào tình trạng miển dịch của bệnh nhân, tác nhân vi khuẩn và tình trạng sử dụng kháng sinh [10].

Tác nhân gây bệnh của áp xe não tùy thuộc vào vị trí xuất phát nhiễm trùng: trực tiếp (nhiễm trùng tai, xoang) thường xảy ra và thường do vi khuẩn tại chổ ở khoang họng (Fusobacterium $\mathrm{spp}$, Bacteroides spp, Prevotella spp, và Streptococci ky. khí). Staphylococcus aureus, coagulase - negative Staphylococci, Pseudomonas spp, vi khuẩn đường ruột, Streptococcus spp, và Clostridium sppp là phố biến nhất ở bệnh nhân viêm xoang và chấn thương. Vi khuẩn lan qua đường máu đến não bao gồm Streptococci viridians, Haemophilus, và Enterococci có thể xảy ra ở những bệnh nhân có bệnh tim bẩm sinh. Nấm (Cryptococcus spp, Aspergillus spp, họ Zygomycetes, Histoplasma capsulatum, Blastomyces dermatitidis) và ký sinh trùng (Emtamoeba histolytica, Angiostrongylus spp, Tinea spp) gây ra áp xe não không phổ biến và thường nhin thấy trong cơ địa ức chế miễn dịch và suy yếu [4],[6].

3.3. Cânn lâm sàng chẩn đoán áp xe não: Chẩn đoán áp xe não qua 2 trường hợp bên cạnh lâm sàng thì việc xác định trên hình ảnh CT/ MRI giúp đánh giá chính xác vị trí, kích thước, và các cấu trúc xung quanh giúp rất nhiều trong việc chẩn đoán, điều trị và tiên lượng. Cũng tướng tự với các nghiên cứu, hình ảnh CT có cản quang / MRI cản từ có giá trị cao trong chẩn đoán, điêu trị và theo dõi bệnh.

Bên cạnh đó, trong những trường hợp nhiễm trùng qua đường máu cần cấy máu làm kháng sinh đồ. Môt số trường hợp phải dẫn lưu dich não tủy thắt lưng để cấy dịch tìm tác nhân gây bệnh và xét nghiệm tế bào trong dịch não tủy. Giúp xác định tác nhân gây bệnh và cho kháng sinh phù hợp trong những trường hợp không đáp ứng với điều trị kháng sinh theo kinh nghiệm.
3.4. Điêu trị áp xe não do tai: Áp xe não do tai có thể gây ra biến chứng nặng và tỷ lệ tử vong cao ở các nước đang phát triển. Tốn kém cho việc chẩn đoán, điều trị và quản lý các biến chứng nội sọ của áp xe não do tai. Chẩn đoán áp xe não dựa vào lâm sàng và hình ảnh học CT scan/ MRI. Thông thường, điều trị áp xe não do tai bao gồm chọc hút mủ từ ổ áp xe, xác định vi khuẩn, tế bào và mô bệnh học. Kháng sinh thích hợp khởi đầu, quyết định phẫu thuật khi cần thiết. Phụ thuộc vào sự lan rộng vào các thành phần mô não, kích thước và số lượng ổ áp xe, dẫn lưu ổ mủ được thực hiện hoặc qua mở sọ và dẫn lưu hoặc xuyên qua 1 lổ khoan. Một số trường hợp bóc trọn bao ổ áp xe. Sau dẫn lưu ổ mủ, mở xương chủm có thể đước thưc hiên để tránh tái phát và giải quyết triệt để ổ nhiễm trùng. Xác định vi khuẩn gây bệnh và phổ kháng sinh thích hợp truyền tĩnh mạch sẽ cho tiên lượng tốt cho bệnh nhân [9].

3.5. Tiên lượng: Tỷ lệ tử vong của áp xe não cao hơn $25 \%$, nếu bệnh nhân không được điều trị thích hợp, có thể dẫn đến biến chứng đến $70 \%$ [8]. Nhiễm trùng hê thần kinh trung ương do tai có thể do cà 2 nguyên nhân viêm tai giữa cấp hoă̆c mạn [2].

Một nghiên cứu cho kết quả $56,3 \%$ có biến chứng nôi so tổn thương đơn lẻ và $43,7 \%$ biến chứng nội sọ biến chứng nội sọ tổn thương đa ổ. Viêm màng não là biến chứng nội sọ phổ biến nhất $43,7 \%$, kế đến là thuyên tắc xoang tĩnh mạch bên $31,2 \%$, áp xe tiểu não $18,7 \% \ldots[3]$.

\section{KẾT LUÂN}

Áp xe não là một tình trạng lâm sàng nặng nề, nếu không chẩn đoán kịp thời có thể gây biến chứng nặng nề và có thể tử vong. Xác định các yếu tố nguy cơ và điều trị hiệu quả là chính yếu cho tiên lượng tốt cho bệnh nhân. Hầu hết các áp xe não do tai đều có ổ nhiễm trùng nguyên phát ở tai.

\section{TÀI LIÊU THAM KHẢO}

1. Bartnik W., Bartnik-Krystalska A. (2000), [Results of the therapy in otogenic intracranial complication in ENT Department of Voivodeship Hospital in Kalisz]. Otolaryngol Pol, 54 (4), 383-8.

2. Chew Y. K., Cheong J. P., Khir A., BritoMutunayagam S., Prepageran N. (2012), Complications of chronic suppurative otitis media: a left otogenic brain abscess and a right mastoid fistula. Ear Nose Throat J, 91 (10), 428, 430.

3. Dubey S. P., Larawin V., Molumi C. P. (2010), Intracranial spread of chronic middle ear suppuration. Am J Otolaryngol, 31 (2), 73-7.

4. Grigoriadis E., Gold W. L. (1997), Pyogenic brain abscess caused by Streptococcus 
pneumoniae: case report and review. Clin Infect Dis, 25 (5), 1108-12.

5. Hafidh M. A., Keogh I., Walsh R. M., Walsh M., Rawluk D. (2006), Otogenic intracranial complications. a 7-year retrospective review. Am J Otolaryngol, 27 (6), 390-5.

6. Ionita C., Wasay M., Balos L., Bakshi R. (2004), MR imaging in toxoplasmosis encephalitis after bone marrow transplantation: paucity of enhancement despite fulminant disease. AJNR Am J Neuroradiol, 25 (2), 270-3.

7. Lu C. H., Chang W. N., Lin Y. C., Tsai N. W. Liliang P. C., Su T. M., Rau C. S., Tsai Y. D.,
Liang C. L., Chang C. J., Lee P. Y., Chang H. W., Wu J. J. (2002), Bacterial brain abscess: microbiological features, epidemiological trends and therapeutic outcomes. Qjm, 95 (8), 501-9.

8. Osma U., Cureoglu S., Hosoglu S. (2000), The complications of chronic otitis media: report of 93 cases. J Laryngol Otol, 114 (2), 97-100.

9. Sennaroglu L., Sozeri B. (2000), Otogenic brain abscess: review of 41 cases. Otolaryngol Head Neck Surg, 123 (6), 751-5.

10. Tonon E., Scotton P. G., Gallucci M., Vaglia A. (2006), Brain abscess: clinical aspects of 100 patients. Int J Infect Dis, 10 (2), 103-9.

\section{THỰC TRANG TRẦM CẢM CỦA NGƯỜI NHIỄM HIV/AIDS ĐANG ĐÎ̂̀U TRI ARV TẠI 2 PHÒNG KHÁM NGOẠI TRÚ TỈNH THÁI BÌNH}

\section{TÓM TẮT}

Mục tiêu: Mô tả thực trạng trâm cảm của người nhiểm HIV/AIDS đang điều trị ARV tại 2 phòng khám ngoại trú tỉnh Thái Bình năm 2019. Đối tượng nghiên cứu: bệnh nhân HIV/AIDS người lớn $\geq 18$ tuổi đang điều trị ARV. Phương pháp nghiên cứu: Phương pháp mô tả thông qua cuộc điêu tra cắt ngang. Kết quả nghiên cứu: Tỷ lệ trầm cảm ở người bệnh điều trị ARV là $36,3 \%$. Người bệnh nam có tỷ lệ trầm cảm thấp hơn người bênh nữ $(35,5 \%$ và $37,3 \%$, $p>0,05)$, nhóm tuổi có tỷ lệ trâm cảm cao nhất là tứ 50 tuổi trở lên $(75,4 \%)$, tỷ lệ thấp nhất ở nhóm 30-39 tuổi chiếm 18,6\%. Trong số những người bệnh ARV $82,8 \%$ người thất nghiệp; $65,8 \%$ nông dân; $26,1 \%$ người làm lao động tự do có dấu hiệu trầm cảm. $59,5 \%$ những người nhiễm HIV/AIDS sử dụng ma túy có dấu hiệu trầm cảm.

Tư khóa: Trầm cảm; HIV/AIDS; Thái Bình.

\section{SUMMARY \\ DEPRESSION SITUATION OF HIV/AIDS PATIENTS WHO TREATED HIV/AIDS WITH ARV AT 2 OUTPATIENT CLINICS IN THAI BINH PROVINCE}

Objectives: Describe the depression situation of HIV / AIDS patients who treated HIV/AIDS with ARV at 2 outpatient clinics in Thai Binh province in 2019. Subjects: HIV / AIDS patients adults $\geq 18$ years old being treated with ARV. Method: Descriptive method through cross-sectional survey. Results: The prevalence of depression in HIV patients was 36,3\%. Male patients had a lower rate of depression than female patients $(35,5 \%$ and $37,3 \%, p>0.05)$. Patients

\footnotetext{
${ }^{1}$ Trường Đại hoc Y Dược Thái Bình

${ }^{2}$ Trung tâm kiểm soát bênh tất tỉnh Thái Bình

Chịu trách nhiệm chính: Ngô Văn Mạnh

Email: manhsdh@gmail.com

Ngày nhận bài: 22.6.2021

Ngày phản biên khoa họ: 23.8.2021

Ngày duyệt bài: 30.8.2021
}

Ngô Văn Mạnh ${ }^{1}$, Bùi Thị Hồng Vân ${ }^{2}$

50 years of age and older had the highest rates of depression, the lowest rate in the group of 30-39 years old accounted for $18.6 \%$. Among patients, $82,8 \%$ were unemployed; $65,8 \%$ of farmers; $26,1 \%$ of self-employed workers showed signs of depression $(p<0,05) ; 59,5 \%$ of HIV patient used drug had signs of depression.

Keywords: Depression; HIV/AIDS; Thai Binh

\section{I. ĐĂT VẤN ĐỀ}

HIV là một bênh lây nhiễm đai dich có tác động tới xã hội lớn nhất từ trước đến nay. Bệnh gẩy suy giảm miê̂n dịch và nhạy cảm với một loạt các loại nhiễm trùng cơ hội và nhiễm trùng khác cũng như sự phát triển của các bệnh ác tính nhất định [1]. Cùng với sự điêu trị nhằm ức chế sự sản sinh của virus HIV bằng thuốc $A R V$ và điều trị các bênh thực thể liên quan đến HIV, người bệnh HIV cũng được chăm sóc, hỗ trợ nhằm tăng cường sức khỏe thể chất. Tuy nhiên, khi sức khỏe thể chất được đảm bảo thì sức khỏe tâm thân của người nhiễm HIV cũng là một trong những vấn đề cân được quan tâm và can thiệp nhằm nâng cao hiệu quả điêuu trị cho họ. Người bệnh nhiểm HIV có thể gặp phải những ảnh hưởng tâm lý xã hội, các vấn đề sức khỏe tâm thân bắt đầu từ rất sớm ngay khi có chẩn đoán ban đâu và có thể phát sinh trong cả thời gian điều trị bệnh. Các vấn đề phổ biến thường gặp phải là trấm cảm, lo âu và làm dụng các chất gây nghiện. Trong đó, trâm cảm là biến chứng thân kinh phổ biến nhất ở bệnh nhân nhiễm HIV và hạn chế đáng kể chất lượng cuộc sống của bệnh nhân HIV/AIDS [8].

Các nghiên cứu trên thế giới cũng cho thấy việc điều trị những người bệnh trầm cảm cũng thực sự khó khăn nếu như họ không tự nhận thức được vấn đề họ gặp phải. Các nhà nghiến 